\begin{abstract}
Др Зоран Живковић
Завод за уџбенике Београд

zoranzivkovic@live.com

zoran.zivkovic@Zavod.co.rs—https://doi.org/10.18485/ai_san_o_gradu.2018.ch15
\end{abstract}

\title{
МЕДИТЕРАН И САН О ГРАДУ
}

Како је Медитеран био предодређен за пловидбу и комуникацију између разних светова, први велики градови настали су на обалама његових мора. У историји урбаног и града, уосталом, као и и поводом много тога у историји света који познајемо све је почело баш на Медитерану, и то у античкој Грчкој, тој „традицији свих традиција“.

И док су стари Грци у својим градовима живели у складу с природом, окружени „осмесима, сунцем и морем“, на северним обалама Јадрана настао је један нововековни град који је постао синоним за пуноћу и богатство медитеранског чулног доживљаја. Венеција и градови на Медитерану не могу се замислити без једног типичног медитеранског органског друштвеног догађаја какав је карневал.

Кључне речи: Медитеран, Атина, Венеција, град, комуникација, урбано, полис, држава сунца, карневал

Град и урбано одувек су једно од суштинских својстава медитеранског идентитета. Медитерански човек свет око себе гледа из визуре градског и урбаног, што је опет последица сталне упућености на комуникацију, као незаменљиви поглед на свет, али и основни егзистенцијални предуслов медитеранског начина живота. И све се то јасно осећа и у оним скровитим малим приморским местима, баш као и у највећим ме- 
дитеранским мегалополисима. Медитерански градови, огледајући се у сјају велике звезде која је непрестано окренута ка њима, као да представљају небројене и велелепне покушаје човека да ту, на обалама топлих медитеранских мора, оствари идеал града и полиса сунца.

За ту метафору најзаслужнији је доминиканац Томазо Кампанела, један од најзначајнијих филозофа хуманизма и ренесансе, који је под утицајем Платонове Државе и Уйойије Томаса Мора написао и 1602. објавио Civitas Solis (Граg суни,а). Сунце и љубав су највиши у хијерархији Кампанелиног идеалног града сунца, који за основни циљ има културу и људску срећу.

Према познатом грчком урбанисти Константиносу Доксијадису, стручњаку за област екистике, мултидисциплинарне науке о човековим насељима, око 10.000 година човек је обитавао у селима, да би у последњих 8.000 година створио и развио нове облике насеља - вароши и градове. Предност села дуго је била у стабилности и равнотежи, али су оне, с друге стране, на селу исувише чврсто чуване да би уопште могло да дође до неког раста и развоја. Пре него што је постао центар комуникације, град је најпре био контролни центар који је разбио шкрту саможивост и сањалачки нарцизам сеоске културе, сматра Луис Мамфорд у својој знаменитој студији Граg у хистиорији (1988).

У многим покушајима да се одговори на питање шта је заправо град можда је најупутније дефинисати га као веома густо насељени, зидом ограђени и ограничени простор. Управо у том ограђеном простору настао је град, доносећи свој најважнији феномен урбаног, чиме је фасцинантно променио свет који познајемо и у којем живимо.

Урбани преображај пратила је, или му је можда чак и претходила нека врста несвесног колективног уздизања према духовном. Град је убрзо постао главни 
фактор човекове трансформације, омогућујући му да потпуно изрази своју личност. Градови су донели проширење људске енергије и пораст онога што би, не само за ову прилику, могли назвати људско „ја“.

Из данашње перспективе, могло би се рећи да је стварање градова је био процес обједињавања раван нуклеарној реакцији јер је ослободио и произвео скоро необјашњиву експлозију људске енергије. Град је већ толико преобликовао човека да се зато без претеривања може рећи да је преобликовање савременог човека и заиста дело града. Временом је град створио један облик живота који ће својом смисленошћу надилазити почетне циљеве који су га створили. Или како је то Аристотел рекао: „Људи се окупљају у граду да би живели; они тамо остају да би живели добрим животом“.

Први градови настали су покрај река, поред оних водених површина које је човек тог доба могао некако да савлада. Али тек с освајањем вештина градње пловила и пловидбе, управо на обалама Медитерана почиње прави развој градова.

Оно на чему је град заснован и потом се око њега ширио, био је обредни религиозни комплекс који се састојао од палате, храма и светилишта. Потом је насушна потреба за дијалогом, настала поред храма, просто растући сама од себе, била пресудна за стварање и развој градова на Медитерану. Дијалог је један од најважнијих израза градског живота. Уједно, он је омогућио и тај први човеков искорак из племенског конформизма, у којем није било могуће откриће свести о самом себи нити било какав развој сопствене личности.

Дијалог ипак није био део првобитне функције града, јер му је претходило то почетно уношење богате људске разноликости у затворени урбани амфитеатар. Тек тада је настао дијалог који се претворио у оно што би се могло назвати драмом града. 
Још од античке Грчке познат је став да се само тамо где се цене разлике и подноси опозиција борба заиста може претворити у дијалектику. Тек стварањем таквог културног и демократског амбијента и атмосфере, град је организовано и развио своју економију и постао место које одиста сузбија физички и подстиче духовни рат.

Захваљујући тако организованом друштвеном и економски привлачном градском амбијенту, као и медитеранској комуникацији, први велики градови, претече савремених мегалополиса, тих џиновских „мелтинг потова“ са својом моћном центрипеталном силом која све привлачи, настали су на Медитерану.

Са Александријом, Римом и Константинопољем, који су имали по неколико стотина хиљада становника, ван Медитерана једино је могао да се мери Пекинг.

Први мегалополис у историји и први град који је пре нове ере досегао милион становника био је Вавилон, да би Рим био први који је имао и више од милион. Током нове ере број од милион становника, поред неких кинеских градова (Хангчао и Пекинг) и могуће астечког Мексика, у периоду од VI до IX века први је достигао Константинопољ, док је Лондон био први град у западној Европи који је премашио милион становника и то тек 1800. године (Доксијадис 1982: 246).

Најзначајнија новина и вредност урбане културе била је у чињеници да је управо она развила специјализовани рад. У граду је први пут специјализовани рад постао свакодневно и искључиво занимање. Као резултат тога, специјализовани радник („увећана рука“ или „око“) усавршио се и постао у свом делу посла тако ефикасан како без те специјализације не би никада могао постати.

Како је Медитеран био предодређен за пловидбу и комуникацију између разних светова, било је више него природно да први велики градови настану на обалама медитеранских мора. Снага и моћ тих меди- 
теранских градова била је углавном заснована на незаменљивој улози поморске трговине и монополу у дистрибуцији разних прекоморских богатстава. Како су ти стари медитерански градови, због свог богатства, били стално на мети пљачки и похара, временом би се опасали моћним зидовима, који данас својом древношћу и сугестивном лепотом сведоче о прохујалим временима негдашње историје. Али ти моћни физички зидови медитеранских градова имају и важно симболичко обележје. Јер, улазак у те градове, кроз њихова велика градска врата, некада је представљао изузетно искушење у сусрету са разним, често невероватним сликама и најнеочекиванијим променама. Нешто што би се данас у савременим филмовима и књигама прожетим научном фантастиком можда једино могло поредити са тзв. временским капијама.

У историји урбаног и града, уосталом, као и поводом много тога у историји света који познајемо, све је изгледа почело баш на Медитерану, и то у античкој Грчкој, тој „традицији свих традиција“. И то управо на главном атинском тргу, где су се догодили људи и збили догађаји који су пресудно утицали на историју савремене светске цивилизације.

За историју града, каквим га данас подразумевамо, пресудна су вероватно била већ прва окупљања око храма, која су тако најпре одредила и учврстила постојање главног градског трга. А затим је уследило одвајање тог најдинамичнијег центра града, агоре, од самог храма. То одвајање састајалишта за свакодневне световне потребе од узвишеног храма, посвећеног жртви и молитви боговима, у Грчкој се догодило брже него у Месопотамији.

Средиште и централно место око којег се основао град, више него вероватно, настало је још у време раних 
друштвених заједница, онда када је у њима сазрела свест о потреби да неке послове обављају заједнички како би се постигла и одржала друштвена равнотежа коју су често нарушавали насиље, крађа, лични сукоби, које је углавном покретала жеља за осветом. Зато је место где се и после највећих сукоба ипак постизало помирење и бар за одређено време установљавао мир било нужно.

Временом се то место претворило у агору, која је постала више него оригинална старогрчка урбанистичка креација будући да је обухватала и обједињавала више важних урбаних функција. Био је то истовремено и главни градски трг и верско средиште града, место на којем су се налазиле најзначајније градске и верске грађевине, које су служиле политичком и верском животу полиса. На агори се и молило и светковало, док су се боговима приносиле жртве. Ту се и судило, трговало и одлучивало о најзначајнијим стварима и питањима за свакодневни живот града, али и о његовој будућности.

Као и многе друге манифестације раног грчког полиса, и агора је описана у Илијаgu, и то у оквиру првог потпуног описа свакодневног живота грчкога града који је Хомер сажето дао у приказу златних и сребрних слика на легендарном Ахиловом штиту. Агора је и ту место где се састају грађани да би у конкретном случају одлучили да ли је убица платио довољну крвну оштету родбини убијеног. „Седећи на углачаним каменовима усред посвећеног круга“, старци су доносили одлуке.

Стару Грчку су неки филозофи описивали као огромну медитеранску земљу саткану од сунца и разговора. Најважнији разговори у њој одвијали су на централним градским местима поред тржница, које су обично биле тик уз храмове и најзначајније административне зграде, тако заједно чинећи главни градски трг. Старогрчка реч аі̄оразеин и дословно значи упути- 
ти се на трг да би се чуло шта се прича. То подразумева причање, куповање, продавање и сусрете са пријатељима. Али та реч и означава и одлазак из свог дома на трг без сигурних и утврђених идеја и разлога, да би се „дангубило“до ручка. Аїоразеин има и свој партицип,

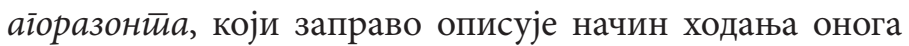
који се упутио на трг, из свих ових разлога. Тај партицип понајвише представља Медитеранца који држи руке на доњем делу леђа и углавном се полако креће ван неких утврђених линија и путања, и као да при том још и оклева. На крају се он полако утапа у вреву медитеранског трга, нестајући у једном трену у тим титравим сликама од гестова, погледа, галаме који чине препознатљиву слику медитеранског света, било некада у древној Грчкој, било данас негде на италијанским или далматинским и бокељским обалама, с ове стране Јадрана.

Гледано из данашње перспективе, стварни значај грчкога града омогућила је чињеница, како тврди Луис Мамфорд, да није био ни премали, али ни превелик, ни пребогат ни пресиромашан. Славни антички грчки градови, супротно веровањима демографских статистичара, пре потврђују да се важност једног града не мери бројем његових становника, већ његовим остварењима у уметности, култури и политичкој мисли. Антички грчки град је на тај начин очувао људску личност, коју су лако могли да угуше њени сопствени колективни производи. Вредност јелинског урбаног искустава јесте и у чињеници да је све то остварено укључујући истовремено све урбане институције, које су могле ујединити људе у мишљењу и на делу.

Ниједан град, ма колико био велик, никада није имао и окупио толико много стваралачких личности колико је то успело Атини, и то само у току једног века. У њој су човеков страх од непознатог, али и радозна- 
лост за сазнањем, заједно родили и религију и науку и филозофију. Атина у V веку пре Христа била је чудо које се догодило на нешто више од два квадратна километра, и какво се више миленијумима неће поновити.

Било је то, ипак, не претерано дуго раздобље у којем су се „састали путеви богова, природе и људи“. У тој генерацији Атињана који су најпре успели да одбију персијску инвазију остварила се идеја потпуне аутономије човека, наметнувши се целокупном тадашњем друштву, дајући истовремено незаборавни печат свим његовим облицима.

Из данашње перспективе, можда је најважније историјско остварење у древној Атини, као објашњење свих њених успеха, било то њено налажење златне средине између јавног и приватног живота. Тако је готово сваки Атињанин, кад дође на ред, бар једном учествовао и вршио јавне послове, било као члан еклезије или сабора, било као надзорни орган који брине о спровођењу донетих одлука. Из данашње перспективе, грчки полиси, ти градови-отаџбине, градови-државе, у почетку су били ништа друго до једна и једина аутономна градска општина са земљиштем и становништвом које ју је окруживало. У полис га је претворила агора, његов најважнији животни орган, јер су на агори утврђивани закони, устав, уз сталну расправу о свим питањима политичког живота једнога полиса.

Живот грађанина Атине углавном се одигравао на тргу, где је градска скупштина заседала од јутра до мрака. Ондашњи Атињанин није долазио само на гласање, већ је велику пажњу посвећивао раду скупштине. Како су у Атини државни интереси били неразлучни од приватних, стално присуство и учешће у раду скупштине било је услов да би на крају њени грађани могли савесно да гласају. Када Хомер у Oguсеји жели да 
представи варварство гигантских једнооких киклопа, он не само да помиње да они нити ору, нити сеју већ свему томе посебно додаје да они немају ни закона, ни народне скупштине.

У свом раду „Култура старе Беотије“ наш омиљени хелениста Милош Ђурић овако је видео значај старогрчког полиса:

„Та мала грчка варош-држава није од човека правила аутоматско биће, јер га није подређивала никаквој надљудској свесили, као Хиндуси и Персијанци, ни големој друштвеној организацији, као Асирци и Персијанци, ни великој индустрији и трговини, као Феничани и Картагињани. Како није поданик ни бога, ни краља, ни сатрапа, ни свештеника, него само поданик слободе и славе свога града, сваки грађанин те државе слободно је славио своје богове, бирао своја надлештва, и у јавним скупштинама одлучивао о најкрупнијим државним пословима. Установе у њој нису биле циљ, него средство, и зато се у њој могла да одржи природна равнотежа способности. Таква држава могла је да буде колевка складних интегралних личности какве се никада доцније нису јављале у људској историји. Човек у њој могао је истовремено и да пева драме, и да мисли танане филозофске мисли, и да доноси законе, и да управља флотом, и да изналази законе механике, и да управља државом, и да се бори у војсци као редов, и да се надмеће у Олимпији - једном речју: да развија у себи не знам колико способности, а да ниједна не омета другу. Све се то дешавало зато што је грчка држава била просторно мала, и та мала просторност згушњавала је и људе и ствари, и економију и дух. Згушњавање у простору узрок је згушњавања у времену: држава и њен грађанин у малом простору живе необичном брзином и бескрајном интензивношћу. Оно што обележава 
живот такве државе у времену, јесте брз, елементарни успон, блиставо цветање и рано старење: то је била судбина Хелена.“ (1997: 9)

Улога полиса и данас изгледа величанствено, јер је сваки део града тада живео у личности грађанина. И учествовање у културном животу било је такође, поред службе у већу или суду, саставни део делатности атинског грађанина. Сваког пролећа одржавало се право такмичење драмских писаца, па је тако свака година доносила дванаест нових трагедија, као и шеснаест нових комедија. За њихово извођење ангажоване су стотине хорских певача и плесача. Процењује се да је у „златном“ веку древне Атине написано и приказано најмање две хиљаде комедија и трагедија, док је компоновано и изведено чак шест хиљада нових музичких дела.

У овим уметничким догађајима учествовали су скоро сви атински грађани, а процењује се да је сваке године чак две хиљаде Атињана морало памтити речи и вежбати музику, разне плесне фигуре певача и драмских хорова. Па и већи део публике није представљао само очаране посматраче, већ су се они могли сматрати и критичарима и стручним судијама.

Атински грађанин у V веку пре Христа није био ограничен неким сопственим уским интересовањима или својим положајем, већ је учествовао у разним догађајима који су га водили од храма до Пникса, од агоре до позоришта, од спортске хале до луке у Пиреју, где су се сва поморска и трговачка питања одмах решавала. Такав живот Атињана није био заснован само на пажљивом посматрању света око себе, или само на саветима филозофа који су размишљали и разматрали тај исти свет. Атињани свој живот нису могли да замисле без праве акције и конкретних збивања и догађаја, у којима су очигледно показивали веома снажне емоције. 
Како је расло становништво града, а с њим и сложеност привредног и политичког живота, тако су истовремено на видело испливавале и слабости и ограничења демократије као искључивог система владавине. Чиста демократија захтевала је да се људи састају у интимном кругу, лицем у лице, у малом броју. Поред тога, она је неизоставно захтевала и традиционално суздржавање и учтиви поступак. Управо је Платон наглашавао предност те близине, јер је у својим Законима приметио да „за државу нема ништа боље него да се грађани узајамно познају“ (Ђурић 1997: 136).

Оно што нас данас највише привлачи у слици Атине из V века пре Христа било је нешто дубље органско, можда најближе самој сржи људског постојања. Jep, из данашње перспективе, највиши домашај тога искуства није био никакав нови тип града, већ нови тип човека. Иако се и за саму Атину може слободно рећи да била далеко од тога да буде идеалан град, и поред тога ће у историји остати вечно запамћена понајвише по томе што је створила идеалног грађанина.

У раздобљу нешто дужем од живота једне генерације - отприлике између 480. и 430. године пре нове ере - полис је по први пут попримио облик по коме се разликује од старијих села и градова. За само неколико генерација грађана стасао је нови урбани поредак, идеални град, који је толико видљиво надишао своје архаичне обрисе, своју животну једноличност и устаљено самозадовољство. Грци су граду дали нову компоненту која је у ранијим културама било готово непозната и која до данас остаје опасна за сваки ауторитарни режим и апсолутизам власти. Та компонента је слободни грађанин. Попут Софоклових усамљених хероја, слободни грађанин је био сам свој краљ: деловао је сам и трудио се да сопственом интелигенцијом и својом руком „заустави ход судбине“. 
Грађанин је био баштиник свих добара града. Тај грчки грађанин је оскудевао и у удобностима и комфору, али је његов живот био богат разноврсним доживљајима и искуствима, баш зато што је успео да заобиђе бројне елементе животне свакодневице и „златне“ окове цивилизације, од којих може да се „затупи“, како су тврдили неки старогрчки филозофи.

Као да никада дотле, али ни после, живот људи у градовима није био толико жив, разнолик и богат као у том раздобљу. Рад и доколица, теорија и пракca, приватни и јавни живот, све је то било, како се то данас каже, у некој врсти сталне и ритмичке интеракције. У таквом животу атинског грађанина и уметност и гимнастика, и музика и разговор, и размишљање и политика, и љубав и пустоловина, па чак и рат, само су проширивали и богатили све видове постојања и чинили њихов град тако изузетним и јединственим. Такав град, чије су отеловљење били Сократ и Софокле, у стварности више никада није потпуно остварен. Зато можда и није претерана тврдња да је Атина Солона и Темистокла била већа школа него било каква заједница замишљена у свету Платонових идеја.

Град је управо био тај који је формирао и трансформисао људе тог времена, и то не само у некој школи и академији, већ у скоро свакој делатности, јавној дужности, на сваком састајалишту и у сваком сусрету.

Био је то живи и разноврсни атински свет, који је осећао и собом лако носио оно што бисмо могли назвати лепотом без претеривања и мудрошћу без мудровања. Он је обликовао и изнедрио духове који су имали дубоку усађену свест и жељу за слободом. Такво самообликовање целог човека, та паидеиа, како је називао Вернер Јегер, за разлику од педагогије у најужем смислу, више никада, и ни у једној заједници потом, није се уздигла до тих висина. 
На време када су у Атини „музе биле код куће“ било би сасвим довољно присећање на плејаду филозофа као што су: Анаксагора, Горгија, Протагора, Парменид, Зенон, Мелис, Демокрит, Архелај, Сократ, Платон, Хипија, Продик, Исократ и Антифонт. Ту су и драматичари Есхил, Софокле, Еурипид и комедиограф Аристофан. То је Атина лекара Хипократа и уметника као што су Мирон, Фидија, Праксител, Зеуксид, Иктин, Хиподам, Каликрат, Алкмен, Кресилас и Поликлет. У значајне Атињане тог доба спадају и историчари Херодот, Тукидид и Ксенофонт, као и познати говорници Хиперид, Трасимах и Лисија, али политичари Темистокле, Милтијад, Кимон, Перикле, Аристид и Алкбијад.

Значај Атине из V века пре н. е. у историји људске цивилизације као да понајбоље илуструје једна упечатљива реченица Бертранда Расела: „У том периоду било је могуће, као у мало ком другом, бити у исто време интелигентан и срећан.“

Стари Грци су град учинили богом по мери онога што је у Феgру изнео Сократ тврдећи да звезде, камење и дрвеће не могу ничему да га науче. Јер, оно што он тражи може да се научи само из понашања „људи у граду“. Обожавана идеја полиса у најславнијем периоду старогрчке историје била је заснована на уверењу да би процеси разума могли наметнути меру и ред свакој људској делатности.

Грчка идеја целовитости и калокагатије оличена у изузетним Атињанима током и непосредно после Персијског рата више никада није успела да створи град по тој својој слици. Јер, од IV века и надаље, чинило се да су зграде требало да надоместе велике људе.

Занимљиво је да непосредних сведочења о томе како се живело у старим градовима, изузимајући Атину и Рим, има мање него што би се очекивало, па чак и у књижевним делима чија је радња везана за урбани ам- 
бијент. Зато је говор о Антиохији ретора Либанија, настао 360. пре н. е., више него драгоцено сведочење. И Либаније, попут Аристотела, друштвену улогу града ставља изнад економске и свих других. Он наводи да Антиохија његовог доба има 25 километара улица с колонадама на којима су приватне и јавне зграде биле помешане баш као и данас у најзначајнијим светским градовима. Колико је то било значајно, илуструју то ови редови:

Док њима ходате, наилазите на слијед приватних кућа с јавним зградама посијаним међу њима у одређеним размацима: овдје храм, ондје купатило, на таквој удаљености да су близу свакој четврти, а у сваком случају улаз је у колонади. Што то све значи и какав је смисао овог дугог описа? Мени се чини да је најугоднија, да, и најкориснија страна градског живота управо та друштвеност, тај људски саобраћај, а то се - тако ми Зеуса - налази највише у граду. Добро је говорити и још боље слушати, а најбоље је давати савјете, суосјећати с доживљајима својих пријатеља, дијелити њихову радост и тугу и добивати заузврат њихова суосјећања - ти и безброј других благослова постижу се кад се човјек састаје са својим друговима. Људе у другим градовима, који пред својим кућама немају колонада, раздваја лоше вријеме; мада живе у истом граду, они су заправо исто толико одвојени као да живе у разним градовима [...] Док људи у градовима губе на интимности утолико више уколико даље станују једни од других, у нас, обратно, пријатељство буја у сталном људском саобраћају и развија се у оној истој мјери у којој се тамо смањује. (Мамфорд 1988: 214-215)

У урбаној историји света Антиохија остаје запамћена по још једном ексклузивном модернитету. Наиме, сведочећи, Либаније се хвали да су грађани Антиохије „збацили тиранију сна; овдје светлости сунца 
слиједи свјетлост свјетиљака, надилазећи сјај Египта; у нас се ноћ разликује од дана само по врсти освјетљења. Трговина се одвија и ноћу; неки се баве својим занатом, а остали пјевају или се забављају“ (исто: 215).

И док су стари Грци, живећи у складу с природом, окружени „осмесима, сунцем и морем“, још пре Христа трагали за људском мером ствари, на северним обалама Јадрана настао је један нововековни град који је постао синоним за пуноћу и богатство чулног доживљаја.

Захваљујући понајвише Венецији, том медитеранском граду над градовима, појам среће се и данас везује за поднебље Средоземља, а стара слава Медитерана се још увек поистовећује са златним добом Serenissime.

До настанка Венеције на старом европском континенту никада нису слобода, култура и богатство, тако једновремено и заједно, као у њено време, толико високо одскочили. Све је почело у XIV веку, када је свој трговачки и материјални тријумф Венеција претворила и у политички, па се већ од тада сматра краљицом Јадрана. Од тада па до 1797. Венеција је заиста град златних нити, метропола златних дуката и цекина, афричког злата и средњоевропског сребра, али и краљица бибера, зачина, лековитих производа, свиле и памука. Иако су Наполеонове трупе, поткрај XVIII века ставиле тачку на такву славу и сјај Венеције, њен утицај није престао. Моћ, слава и тај сјај Венецију су претворили у једну од најважнијих медитеранских и европских метропола културе и туризма, како је и данас свет доживљава. Јер, Венеција је данас један од ретких градова на свету која својим посетиоцима, упркос свему пролазном, неумитном и коначном, и даље нуди невероватну и очаравајућу „илузију о заустављеном времену“. Дуго су, још у средњем веку, Срби и Венеција били два удаљена света. Да би након почетних трго- 
вачких веза, у немањићко доба преко Котора, а у доба деспотовине преко Дубровника, посебно развојем штампарства у Венецији, почеле и интензивније културне српско-млетачке везе. Тако је у овом великом космополитском и културном центру, почело веома рано и штампање српских богослужбених књига.

Привредне и културне везе са Венецијом и градовима на италским обалама Медитерана постају тако најзначајнији западни импулси у култури и историји српског народа. Нарочито у оно време када је више векова провео у сенци Агарјана.

У српској књижевној и културној традицији, гледано са италских обала, посебан значај свакако имају и Напуљ и Трст, као и Рим. Али је историјски тријумф Венеције учинио да она вековима има изузетан утицај на српску историју, па стога и на културу, уметност, као и књижевност. Најзначајнији део оног изузетног што су људске руке направиле у Далмацији и Боки Которској, плод је тог сусрета словенства са импулсима државног устројства и једног урбаног тоталитета који је вековима представљала Венеција. Идеал Венеције, као града над градовима, који својим богатством и развојем непорециво одређује и диктира стандарде урбаности и утврђује нове, па и естетске вредности, наставио је тако да живи и после њеног пада. Тај њен утицај, не само на обалама Јадрана, како у начину живота, тако и у градитељству, уметности, књижевности и култури, протегао се до наших дана. Отуда је Венеција изузетна и за за српску културу и књижевност, не престајући да буде инспиративни литерарни мотив у српској књижевности.

Друштвена функцију некадашње грчке агоре, као отвореног простора, задржала се и у латинским градовима у облицима који су познати као: plaza, piazza, grand-place. То су измењени, али, свакако, директни по- 
томци агоре, јер управо ту на отвореном медитеранском простору, окруженом кафанама, кафеима и ресторанима, долази до оних спонтаних сусрета лицем у лице, до сретања у пролазу, до разговора и флерта. Ту се спонтанитет чува и негује, чак и онда када постаје навика.

На Медитерану, као и другде, тај говор на градским трговима није служио само класичној трговинској размени или, као у новије доба, за придобијање туриста и гостију; у свакодневним опуштајућим разговорима на свим већ поменутим местима, у безбројним кафеима, траторијама, пицеријама, тавернама. И овде су говорници придобијали вернике, политичке истомишљенике и неистомишљенике, браћу по докерским и другим, па и радничким и социјалним мукама. Зато су, уосталом као и широм света, и на Медитерану талентовани говорници служили демократији и слободи, али и демагогији и тиранији.

Дуга и богата историја и традиција урбаног Медитерана просто се слила у тргове, као најважније било живота његових градова.

Суштински значај медитеранског трга, од његовог оснивања па до данашњих дана, јесте у комуникацији, том основном својству медитеранске културе и медитеранског живота уопште. У новије време тој толико значајној улози великог медитеранског трга у свакодневном животу приморских градова прави музички споменик подигао је познати италијански кантаутор Лучо Дала веома популарном песмом Piazza Grande, у којој посебно одзвањају његови стихови: „Немам праву породицу / а Велики трг је мој дом“. Не само тим стиховима већ и музиком која магично спаја ширине медитеранских мора и богатство свих тих карневалских боја медитеранског градског живота, Лучо Дала подсећа на заводљиву опуштеност медитеранских градова, где се, не само су- 
ботом и недељом, на отвореном сунцу широког градског трга, у баштама многих ресторана и кафеа, испија магични café espresso уз разговоре „без севера и смера“.

У те општепознате слике медитеранског града спадају и она преподнева, као и време одмах после летње сијесте, недалеко од самих пристаништа и лука, где локални калафати глачају и раде на разним баркама, чамцима и бродовима, који само што нису поново, или можда баш и први пут, окусили море. У карактеристичне градске медитеранске слике спада и сијеста, то време негде иза поднева, поготово лети, када као да све живо дрема и куња, омамљено јарким подневним жаропеком и опојним мирисом мора који нису могле да зауставе ни моћне зидине старих градова.

А онда блажени мир поподневне летње сијесте смењује предвечерња оживелост градских тргова. Почиње припрема за увек толико обећавајуће летње вече, које ће протећи у дугим и титравим играма светлости и сенки на градским фасадама. А када сунце нестане, тамо иза морског хоризонта, медитерански град ће се у једном трену, скоро неприметно, пресвући у ноћ и сва њена тајанства која ће се до раних јутарњих часова стално нудити.

И српска култура, и њена књижевност прожета медитеранским темама, као и историја Медитерана уосталом, показују да је једно од најзначајнијих цивилизацијских искустава човека на земљи, управо његов сусрет са градом. Сусрет са оним градом који је постао сублимација и резултат свих тих медитеранских пловидби и комуникација, која су толико променила човека и убрзала светску историју, економски развој и његов живот. То је сусрет са опчињавајућим, али у исти мах и са оним левијатанским духом града у његовом свакодневном животу. Са свим оним што је град донео свету и цивилизацији. И на крају то је сусрет са градом над градовима, оним којег данас називамо ме- 
галополис, и који се најпре појавио на Медитерану, и понајвише приближио идеалу града као полиса сунца.

У Боки Которској, као уосталом и на целом Медитерану, и она насеља која имају мање од хиљаду житеља имају дух великих градова, јер им је довољан централни градски трг уз мало пристаниште, из којег се може запловити према било којем од могућих земаљских светова.

Како је забележио Симо Матавуљ, иначе писац Розопека, тог у српској књижевности најмедитеранскијег града, у Боки никако нису биле ретке женидбе са странкињама или склапање бракова без обзира на различиту веру младих супружника. Тако се у приповести „Догађаји у Сеоцу“ наводи да Сеоце има „деведесет и пет женских глава [...] Све удате, нити су мјештанке, нити иначе приморске одиве: четири су Гркиње, три Италијанке, двије Рускиње и једна Инглескиња“ (Матавуљ 2007: 253-254).

Сеоце има само двадесетак кућа, али у њему је више странога света него у многим великим градовима дубоко у унутрашњости. То може да потврди и само једна уобичајена шетња главног јунака ове Матавуљеве приповести, иначе угледног поморског капетана, који је заповедао на енглеским, чак и на руским бродовима, али се увек враћао свом Сеоцу:

Достојанствено Амираљ корача и поздравља госпође на прозорима, а кад стигне под своју кућу, која је највећа у Старом Сеоцу, предијељена и са двије капије, стаде пред ону, над којом високо горе, вире двије женске, изврати главу и викну:

- Здравствујте, Надежда Феодоровна! Здравствујте, Ољга Никитина!

- Здравствујте, Мафеј Лукич! - одговоре обје женске у глас, па сиђу пред кућу, гдје се рукују и са Пајлотом, који се клања дубоко (исто). 
У српској епској народној поезији град је представљен познатим сликама, као синоним за изобиље, раскош, господство, али и исто тако и за преваре разних врста, за невероватно људско лукавство, па и разне и оностране силе, чак и смртне опасности.

Најпознатије медитеранске слике откривају и наглашавају ту прогресивну отвореност медитеранског града увек према овом свету и садашњем тренутку. Али, оне, с друге стране, показују и вребајући левијатански дух тога истог града који у себи гута све топлине раних локалних историја и идентитета који се у њега сливају.

Па шта је то онда толико суштинско, да буде тако магично за књижевност, али, што је још више и важније, и за сам живот, у идентитету једног медитеранског града?

Откриће те тајне очито је у једном органском друштвеном догађају за медитеранске градове, познатом као карневал. Чак и у оним мањим градовима и местима на Медитерану где се не одржавају карневали, као да се и даље осећа дух медитеранског карневалског погледа на живот и свет. То својство Медитерану и његовим градовима даје не само толико посебну и тако апартну медитеранску занимљивост већ и наглашени урбани идентитет.

Сваки разговор о књижевности и уметности које настају на медитеранским обалама неизбежно подразумева једну посебну карактеристику урбаног идентитета медитеранске културе, јер, градови на Медитерану тешко да се могу замислити без једног типичног, и за њих толико органског друштвеног догађаја, какав је карневал.

Карневалска слобода извршила је огроман утицај на колективни идентитет приморских градова и 
дала вероватно најважнији печат оригиналној физиономији медитеранског града и ведром хедонистичком оптимизму који он собом носи.

Карневали и медитерански карневалски поглед на живот доносе смех који проистиче из људске природе и животне радости као њене есенцијалне особине. Смех као један могући начин у човековим покушајима да се издигне изнад свеопште пролазности већ и да је тако и разуме и, с неочекиваном мудрошћу, на крају и прихвати.

Али оно што је развој града донео историји свеколике цивилизације у том непрекидном процесу очовечења човека посебно је забележила једна немачка пословица која каже да „градски ваздух има укус слободе“. У медитеранским градовима та слобода је дуго носила и своје карневалско име.

Кроз субверзивност карневалског смеха у односу на своју друштвену стварност, медитерански човек је јасно показивао и жељу, моћ и способност да се управо на тај начин уздигне изнад пролазног и привременог живота.

Универзалност смеха усмереног на све и свакога управо подругујући, исмевајући, негирајући, потврђујући, покопавајући, у једном тренутку почиње да бива лековита, и да препорађа све учеснике карневала. Али оно што је карневалима, као препознатљивом својству медитеранских градова, донело општу популарност, а што се на посебан начин догодило у доба ренесансе, била је рехабилитација плотског и телесног.

Материјално-телесно начело у раблеовским сликама учинило је да Михаил Бахтин сликовитост те народне смеховне културе обележи једном посебном естетичком концепцијом стварности коју је он дефинисао као гротескни реализам. Према Бахтину, основно 
својство гротескног реализма је снижавање, прецизније речено превођење високог, духовног, идеалног и апстрактног на материјално-телесни план, на онај нераскидиви однос између земље и тела. Тако је и најважнији тренутак у наступима средњовековних лакрдијаша настајао онда када се сваки церемонијал и обред преводи и спушта са високих патетичних висина, тамо доле у пределе материјално-телесне низине.

У свим сећањима и сликама медитеранског карневалског живота, као његов заштитни знак, стално лебди и одјекује народни карневалски смех подсећајући нас на онај важан, ако не и суштински извор смеха и комичног уопште, ту дубоку и неуништиву радост коју собом носи људска природа. Хумор, комично, збијање чак и умерених шала, наравно, нису иманентни само приморском, медитеранском амбијенту. Али управо ту, у градовима покрај мора, као нигде другде, они као да су заиста „код своје куће“. Разне сцене, анегдоте и приче прожете аутентичним хумором као део карневала, а још и више тог карневалског погледа на живот, познате су широм Медитерана и у градовима на свим његовим обалама.

Људска насеља су настајала по мери човека и у ограничењима историјског развоја онога што би могли назвати човечанством. А да је мера свих ствари заиста човек, тврдио је још у $\mathrm{V}$ веку пре нове ере познати атински предсократовац и софиста Протагора. Ту знамениту мисао, обухватајући и одређујући нови значај односа између човека и човечанства, у новије време је на упечатљив начин реактуелизовао Џон Дјуи (18591952), познати амерички филозоф, педагог и политички веома ангажовани реформатор. Он је однос човека и човечанства видео овако: „Човечанство није, како се раније веровало, крајњи циљ ради кога је створен свет. Човечанство је незнатна и слабашна ствар, можда само епизода у огромном пространству свемира. За човека, 
међутим, човек је центар свих интересовања и мера вредности“ (нав. према Доксијадис 1982: 30).

Градови на Медитерану, попут Атине, Александрије, Рима, Константинопоља и Венеције, нису само најзначајнији део светске урбане историје, чији развој и домети спадају у звездане тренутке у историји човечанства. Развој живота и цивилизације у градовима на Медитерану и његови разнобојни урбани импулси знатно су убрзали свеопшти ток светске историје. Заувек опчињен својим родним амбијентом, како то Медитеранац и може бити, Пол Валери је то овако назначио:

Шта је тако величанствено као чињеница да су, у току неколико столећа, међу тим народима који живе на обалама овог мора, рођена најдрагоценија и најчистија интелектуална открића: јер управо се ту наука ослободила емпиријског и практичног, уметност се отргла својих симболичких корена, књижевност се јасно издвојила и јасно разделила на јасно различите родове, и, најзад, ту је филозофија опробала готово све могућне начине у посматрању света и себе саме.

Никада, и нигде, на тако скученом простору и за кратко време, не би било могућно говорити о једном таквом превирању духа и таквој продукцији богатства. (Валери 2010: 66)

\section{Извори и литература}

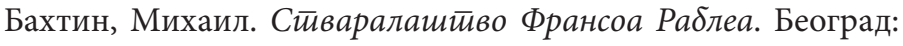
Нолит, 1978. Штампано.

Бродел, Фернан. Меgитерран, Простиор и истиорија. Београд: Центар за геопоетику, 1995. Штампано.

Буркхарт, Јакоб. Кулииура ренесансе у Ийалији. Београд: Дерета, 1991. Штампано.

Валери, Пол. Меgитеранска наgахнућа. Београд: Службени гласник, 2010. Штампано. 
Доксијадис, Константинос. Човек и ірраg. Београд: Нолит, 1982. Штампано.

Ђурић, Милош Н. Кулитурна истиорија и рани филозофски сиичси. Београд: Завод за уџбенике и наставна средства, 1997. Штампано.

Мамфорд, Луис. Граg у хистиорији. Загреб: Напријед, 1988. Штампано.

Матавуљ, Симо. Прийоветике, Сабрана gела. Београд: Завод за уџбенике, 2007. Штампано.

Матвејевић, Предраг. Меgишерански бревијар. Подгорица: ЦИД, 2003. Штампано.

\section{Zoran Živković}

\section{MEDITERRANEAN AND THE DREAM OF A CITY}

\section{Summary}

Being the center of communication and sailing through various and different worlds, Mediterannean coasts were destined to become the place where the first big cities will arise. In the history of urbanity and city altogether, like in many aspects of the world as we know it today, everything started exactly in the Mediterannean, more precisely in the Ancient Greece, that "tradition of all traditions".

And while the Ancient Greeks lived in their cities in harmony with the nature, surrounded by "smiles, sun and sea", one modern city was born on the the northern shores of the Adriatic, city which became the epitome of the fullest experience of senses. Venice and the Mediterranean cities under its direct influence cannot be imagined without a typical Mediterannean organic social event such as carneval.

This paper particularly emphasises the importance of the Mediterannean communicativeness and the two Mediterannean cities, Athens and Venice, for the development of city and urbanity in the history of the civilization and world. 